\title{
The Breakthrough of Another West European Populist Radical Right Party? The Case of the True Finns
}

IN A RECENT REVIEW ARTICLE KITSCHELT NOTED THAT FINLAND, ALONG with neighbouring Sweden, is one of the countries where radical right parties have been unable to make significant headway. ${ }^{1}$ Yet at the European Parliament election in June 2009, the True Finn Party, Perussuomalaisten puolue (PS), gained virtually 10 per cent of the national vote, almost equalling the best result of its 'parent party', the now defunct Finnish Rural Party, Suomen maaseudun puolue (SMP), at the 'earthquake election' of 1970. Following the PS' significant advances at the 2008 local elections, commentators made reference to 'the breakthrough of right-wing populism in Finland', attributing it above all to the immigration question and the problems associated with immigration, such as personal safety on the streets, crime and concern about jobs. ${ }^{2}$ Cochrane and Nevitte go further in viewing the PS as a 'far-right anti-immigrant party'. ${ }^{3}$ Significantly, the Minister for Immigration and Europe, Astrid Thors (Swedish People's Party), has expressed the fear that the PS is developing into a racist party, displaying similar features to other Nordic radical right parties and indeed is in contact with them. ${ }^{4}$ In light of these claims, this article

${ }^{1}$ H. Kitschelt, 'Growth and Persistence of the Radical Right in Post-Industrial Democracies: Advances and Challenges in Comparative Research', West European Politics, 30: 5 (2007), pp. 1176-206.

2 'Professori Martikainen: Oikeistopopulismi teki läpimurron Suomeen', Helsingin Sanomat, 27 October 2008. Also, the television interview with Tuomo Martikainen, Ylen, Ykkösaamussa, 29 November 2008.

${ }^{3}$ C. Cochrane and N. Nevitte, 'Support for Far-Right Anti-Immigration Political Parties in Advanced Industrial States: 1980-2005', paper presented at the 4th General Conference of the European Consortium for Political Research, Pisa, Italy, 6-8 September 2007.

4 'Thors huolissaan perussuomalaisten ulkomaalaisvastaisuudesta', Helsingin Sanomat, 19 October 2008. 
seeks to characterize the PS on the basis of its core ideological features and asks: (1) Is it a populist party? (2) Is it a populist radical right party? The aim is to locate the PS in multi-dimensional space using a careful reading of the party literature as the primary data source and to do so by reference to three fundamental 'isms' attributed to populist radical right parties - that is, populism, socio-cultural authoritarianism and ethno-nationalism (nativism). ${ }^{5}$ It is argued that the PS is indeed a populist radical right party - with Finnishness (suomalaisuus) as its pre-eminent concept - albeit one (thus far) lacking the xenophobic extremism of the likes of the Austrian Freedom Party or the Danish People's Party.

\section{THE GROWTH IN THE PS' SUPPORT}

Whilst Taggart included the SMP in the family of rightist New Populist Parties, ${ }^{6}$ neither the SMP nor the PS has an established place in the comparative party literature. Founded in 1995 when the SMP went bankrupt, the PS is best viewed as a successor party. True, it was designed to be a new party and not simply an SMP mark $2,{ }^{7}$ but there was substantial core continuity and in many respects it was a new party in name only. Timo Soini, the party chair since 1997, has noted that almost all the PS' founding members were former SMP members or supporters and he has readily turned to former SMP parliamentarians to stand as candidates in general and local elections. ${ }^{8}$ Soini, a former SMP party secretary, moreover, has recorded his admiration for (and debt to) the SMP's founder Veikko Vennamo, who deployed a distinctive, emotive and highly original rhetoric to attack three

${ }^{5}$ C. Mudde, Populist Radical Right Parties in Europe, Cambridge, Cambridge University Press, 2007.

${ }^{6}$ P. Taggart, 'New Populist Parties in Western Europe', West European Politics, 18: 1 (1995), pp. 34-51.

7 T. Soini, Maisterisjätkä, Helsinki, Tammi, 2008, p. 84.

${ }^{8}$ In 2007 for example, the former SMP MP Lea Mäkipää's candidacy in the Pirkanmaa constituency contributed substantially to the election of the musician and celebrity Pertti 'Veltto' Virtanen. At the 2008 local government election, the 66-yearold Pentti Kettunen was elected on a substantial vote in the Kainuu district, having previously been an SMP MP, its long-serving organizational secretary for northern Finland and for seven years Veikko Vennamo's political secretary. 'Kainuun vaaliveturiksi Smp:n entinen kansanedustaja', Helsingin Sanomat, 28 October 2008.

(C) The Author 2010. Government and Opposition (C) 2010 Government and Opposition Ltd 
elements in the political establishment in particular. First, there was the personal vendetta against the authoritarian management style of the long-serving head of state Urho Kekkonen (1956-81); $;^{9}$ then there was a summary dismissal of the ruling cartel of parties, particularly Vennamo's former party, the Agrarian-Centre, which was seen to be in league with the president; and finally there was an absolute refusal to conform to the self-censorship practised by a political class concerned not to fall foul of the president and Moscow. ${ }^{10}$

The SMP was a populist party which confronted the Cold War Finnish establishment in the name of the 'forgotten people' (unohdetun kansa) - the 'small man' in town and country. Socio-political conditions, however, altered dramatically between the SMP's breakthrough in 1970 and the election of three PS MPs in 2003. Rapid social structural change transformed Finland from a predominantly agricultural into a Nokia-led, communications-based society and the old class contours gave way to a 'lumpen' tertiary-based salariat concentrated in the cities in the southern third of the country. Accelerated economic modernization was accompanied by equally fundamental institutional and constitutional change. The Soviet Union's collapse meant that office-seeking parties could no longer be excluded from government for 'general reasons' (yleiset syyt) the code for 'unacceptable' in Moscow - and become 'pariah parties' in the manner of the Conservatives, SMP and Christian League in the 1970s and early 1980s. ${ }^{11}$ EU membership, only four years after the USSR's disintegration, revived the historic centreperiphery cleavage whilst also creating a multi-level system of decision-making in which the protection of national interests (and to EU critics the restoration of national sovereignty) became of paramount importance. In addition, the adoption of a new constitution in 2000 largely undermined the president's veto power,

${ }^{9}$ Soini has written that he would not have felt the same urgency to join the SMP if Vennamo had not laid the burden of the political malaise of the 1970s firmly at Kekkonen's door. 'I became a Vennamo supporter and an opponent of Kekkonen and my instinct has not changed since.' Soini, Maisterisjätkä, p. 148.

${ }^{10}$ For a discussion of the various types of self-censorship practised by the political class during the period of 'Finlandized politics', see E. Salminen, Vaikeneva valtiomahti?, Helsinki, Edita, 1996.

${ }^{11}$ D. Arter, 'From a Contingent Party System to Party System Convergence? Mapping Party System Change in Post-War Finland', Scandinavian Political Studies, 32: 2 (2009), pp. 221-39.

(C) The Author 2010. Government and Opposition (C) 2010 Government and Opposition Ltd 
Table 1

The True Finns' Performance in Recent Elections

\begin{tabular}{llr}
\hline Election & $\%$ Vote & Total Vote \\
\hline 2003 general election & 1.6 & 43,816 \\
2004 local government election & 0.9 & 21,417 \\
2006 presidential election & 3.4 & 103,492 \\
2007 general election & 4.1 & 112,256 \\
2008 local government election & 5.4 & 137,446 \\
2009 European Parliament election & 9.8 & 162,571 \\
\hline
\end{tabular}

particularly in respect of the appointment of governments and dissolution of parliament. Finally, the election of three PS MPs in 2003 should be set against the backdrop of a distinctive period of exceptionally broad 'surplus majority', five-party coalition government and widespread reference to Finnish-style 'consensus politics'. The Social Democrat Paavo Lipponen's so-called 'rainbow coalition', formed in 1995, also comprised the post-communist Left Alliance, Swedish People's Party, Greens (until 2002) and the Conservatives! The PS emerged in no small to measure to challenge this consensus. As Soini, its leader, put it at the time: 'In Finland you can hold any opinion you like, except a different one'!

The PS' national vote-share has grown steadily from 1.6 per cent at the 2003 general election to 9.8 per cent at the 2009 European Parliament election (see Table 1). In 2003 it was highly indebted to (the late) Tony 'Viking' Halme, a professional boxer, wrestler and B-movie actor, who, standing as an Independent on the PS' list in the populous Helsinki constituency, gained nearly 38 per cent of the party's total national vote. Finland has a strong preferential electoral system in which voters are obliged to opt for a particular candidate and not simply a party list and individual candidate vote totals then determine the ordering of successful MPs. In other words, citizens simultaneously cast a 'candidate vote' and a 'party vote' and, although by no means a linear rise, it seems that increasing proportions of voters (a narrow majority in 2007) are placing the choice of candidate before that of party in their decision on how to vote. This has been notably the case in the PS and in 2003 no less than 90 per cent of its voters - easily the highest proportion in any of the parties ${ }^{12}$

12 The number of PS respondents, however, was very small.

(C) The Author 2010. Government and Opposition (C) 2010 Government and Opposition Ltd 
- placed the choice of candidate before the choice of party. ${ }^{13}$ It is a fair bet that a 'personal vote' for Halme from those with only a weak party identification accounted for much of this exceptionally high figure. ${ }^{14}$ Halme's ideas, which included sending paedophiles, rapists and drug-dealers to Russian prisons to serve their sentences, doubtless provided a protest channel for young persons who would not otherwise have turned out to vote.

However, it was Soini's performance as his party's candidate at the 2006 presidential election - when he gained 3.8 per cent at the first round of voting - that raised the PS' profile, gave it electoral credibility and enabled it to recruit support away from the urban 'deep south'. (There is an interesting parallel here in that Vennamo's presidential candidacy in 1968 was decisive for the SMP's parliamentary breakthrough two years later.) Soini, who has attracted substantial media interest, has been the PS' 'trump card' ever since. In an attempt to raise the PS' profile, he has accused the three 'old cartel parties' of 'kidnapping publicity' and by announcing that he was his party's official 'prime minister candidate' at the 2007 general election sought to highlight the television companies' unfair concentration on the leaders of the three larger parties. ${ }^{15}$ Soini gained the third highest poll of any candidate at the 2007 general election and the highest individual tallies at both the 2008 local elections and the 2009 European Parliament election. Indeed, he has indicated that he will serve only two years as an MEP before returning to lead the PS into the 2011 general election. All in all, there has been substantial growth in the PS' support in recent elections, but does this denote the breakthrough of a populist radical right party in Finland?

\section{THE PS: A POPULIST PARTY?}

Schedler has noted that populism has been associated with a broad array of anti-attitudes - among them anti-elite, anti-establishment, anti-modern, anti-urban, anti-industrial, anti-state, anti-foreign,

${ }^{13}$ Finnish voters are obliged to vote for an individual candidate and cannot simply vote for a party list.

${ }^{14} \AA$ Å. Bengtsson and K. Grönlund, 'Ehdokasvalinta', in H. Paloheimo (ed.), Vaalit ja demokratia Suomessa, Porvoo, WSOY, 2005, p. 237.

${ }^{15}$ T. Anttila, 'Veretön pääministeritaisto', in V. Pernaa, M. K. Niemi, and V. Pitkänen (eds), Mielikuvavaalit, Keuruu, Otava, 2007, pp. 118-19. 
anti-intellectual and anti-minority sentiments. ${ }^{16}$ Anti-politicalestablishment actors, he posits, declare war on the political class - in the pejorative sense of the stratum of professional politicians. When viewed in this light, the PS is unequivocally an anti-establishment party, asserting in line with Abedi the existence of a fundamental divide between the political establishment and the people. ${ }^{17}$ The PS leader Soini has displayed the classic range of 'anti-attitudes', particularly the anti-elitism and anti-intellectualism of his mentor Veikko Vennamo. Typically, for example, he has asserted that 'book-learned theoreticians, arrogant bureaucrats, cold-hearted technocrats, uncomprehending centralizers, big-money worshippers and smooth avant-garde thinkers do not trust the people. They do not value the people's views because they believe the people are stupid and indifferent and that all wisdom rests with the experts and an elite that is divorced from everyday life. ${ }^{18}$

The 2003 election manifesto also well illustrates the anti-elite, anti-consensus character of the party. It is couched in a strident and colourful Veikko-Vennamo-style rhetoric and even revived some of the vocabulary of the SMP's founder - the dissociation with the 'sleaze merchants' (rötösherrat) in the 'old parties', for example. The manifesto was unrestrained in its critique of the 'unnatural, unprincipled and overbearing' manner of Lipponen's 'rainbow coalition' (this was reminiscent of Haider's constant attacks on Grand Coalition government in Austria between 1986 and 1999), insisting that the lack of political alternatives constituted a direct threat to genuine democracy in Finland. The 'old parties', it held, underestimate the people and believe the nation is incapable of making independent choices; Finland is managed by a 'consensus alliance' of big unions and big business and those holding divergent views are dismissed as trouble-makers.

The PS also conforms to the conventional wisdom that populism is a phenomenon embedded in democratic systems which is confrontational but not anti-democratic. It seeks to oppose the minority that is

${ }^{16}$ A. Schedler, 'Anti-Political-Establishment Parties', Party Politics, 2: 3 (1996), pp. 291-312.

${ }^{17}$ A. Abedi, Anti-Political Establishment Parties: A Comparative Analysis, London, Routledge, 2009, p. 12.

18 Soini, Maisterisjätkä, p. 162.

๑ The Author 2010. Government and Opposition @ 2010 Government and Opposition Ltd 
preventing the demands of 'the people' from being realized ${ }^{19}$ but, whilst associated with a broad range of 'anti-attitudes', it is not antisystemic in the sense of rejecting participation in the institutions of representative democracy. In Bergh's terms, ${ }^{20}$ populism channels 'elite protest' rather than 'system protest'. Populist movements and parties may (or may not) be 'a by-product of the democratic malaise'21 or a manifestation of what Canovan has referred to as 'the insoluble paradox of democracy', ${ }^{22}$ but they are not generally anti-democratic in the sense of seeking to dismantle the constitutional and institutional structures of representative democracy. ${ }^{23}$ The PS has in fact canvassed a model of populist democracy which places the emphasis on the 'by' and 'of' elements in Lincoln's classical formulation. The 2003 election manifesto states that the PS trusts the people, their strength and creativity and notes that a sustainable society is built from the bottom up by listening to the people. Well-grounded criticism is dubbed 'hindsight' and 'populist' but it is argued that it is futile to seek to intimidate the nation with the spectre of populism. The PS will ensure that so-called populist themes, which concern the nation, rise to the fore in the coming election campaign. The 2003 manifesto concluded that the PS will provide a channel for 'new ideas, bold initiatives and sensible protest' and serve as a counterpoise to the compulsory consensus demanded by the political establishment. In short, the PS has eschewed the pejorative connotations of populism and sought unashamedly to market what Soini calls responsible populism.

There is general agreement in the comparative literature that populism is confrontational, chameleonic, ${ }^{24}$ culture-bound and context-dependent, varying from polity to polity and 'taking on the

19 A. Ware, 'The United States: Populism as Political Strategy', in Y. Mény and Y. Surel (eds), Democracies and the Populist Challenge, Basingstoke, Palgrave Macmillan, 2002, pp. 101-19.

${ }^{20} \mathrm{~J}$. Bergh, 'Protest Voting in Austria, Denmark and Norway', Scandinavian Political Studies, 27: 4 (2004), pp. 367-89.

${ }^{21}$ Mény and Surel, Democracies and the Populist Challenge, p. 11.

${ }^{22}$ M. Canovan, 'Taking Politics to the People: Populism as the Ideology of Democracy', in Mény and Surel, Democracies and the Populist Challenge, pp. 25-44.

${ }^{23}$ P. Ignazi, Extreme Right Parties in Western Europe, Oxford, Oxford University Press, 2003, p. 30.

${ }^{24}$ P. Taggart, 'Populism and the Pathology of Representative Politics', in Mény and Surel, Democracies and the Populist Challenge, p. 70.

() The Author 2010. Government and Opposition @ 2010 Government and Opposition Ltd 
hue of the environment in which it occurs' ${ }^{25}$ The context-dependency of populism appears particularly important when considering the phenomenon in post-communist Central Europe, ${ }^{26}$ where the party systems are less stable, and institutionalized anti-party sentiment persists. On the basis of case studies of Bulgaria, Hungary, Poland and Slovakia, Smilov and Krastev distinguish between soft populism, which is the West European democratic variety, and hard populism, which if not expressly anti-democratic nonetheless confronts the basic precepts of liberal democracy. 'Hard populism' threatens the constitutional framework by challenging fundamental liberal principles such as the protection of individual and minority rights. Whilst the debate about the relationship between populism and democracy has spawned broad agreement about many of its fundamental properties, there remains, paradoxically, much less of a consensus about what precisely populism is - whether in West or post-communist Europe.

For many scholars populism is either a mass movement, ${ }^{27}$ specific style of communication ${ }^{28}$ and/or a political mobilization strategy. Eatwell, for example, argues that 'populism is best seen as a style rather than a specific body of thought', adding that 'it has no clear ideology and tends to be negative'. ${ }^{29}$ In similar vein Luther has noted how the populist vote maximization strategy of the Austrian Freedom Party (FPÖ) in the 1990s produced inconsistency in the party's policies - a type of 'ideological promiscuity' born of electoral opportunism. ${ }^{30}$ Equally, there are those writers, albeit scarcely a majority, who have viewed populism as an ideology, although it is pointed out that

${ }^{25}$ R. Heinisch, 'Success in Opposition - Failure in Government: Explaining the Performance of Right-Wing Populist Parties in Public Office', West European Politics, 26: 3 (2003), p. 93.

${ }^{26}$ T. S. Di Tella, 'Populism into the Twenty-First Century', Government and Opposition, 32: 2 (1997), pp. 191-3.

${ }^{27}$ R. R. Barr, 'Populists, Outsiders and Anti-Establishment Politics', Party Politics, 15: 1 (2009), p. 44.

${ }^{28}$ J. Jagers and S. Walgrave, 'Populism as Political Communication Style: An Empirical Study of Political Parties' Discourse in Belgium', European Journal of Political Research, 46: 3 (2007), pp. 319-45.

${ }^{29}$ R. Eatwell, 'Introduction: The New Extreme Right Challenge', in R. Eatwell and C. Mudde (eds), Western Democracies and the New Extreme Right Challenge, London and New York, Routledge, 2009, p. 12.

${ }^{30}$ K. A. Luther, 'Electoral Strategies and Performance of Austrian Right-Wing Populism, 1986-2006', Keele European Parties Research Unit Working Paper 24, Keele University, 2007, p. 7. 
the spatial location of populism will be determined by 'additives' from other ideologies. The ideological 'overlay' will dictate the particular form of populism and, by extension, allow us to consider the most appropriate characterization of the PS' populism.

Mudde notes that social populism is left-wing populism, combining socialism and populism, whereas neo-liberal populism is right-wing populism, combining economic liberalism and populism. ${ }^{31}$ Abts and Rummens hold that left-wing versions of populism will refer to socioeconomic relations and identify the people with the labourers and farmers'. ${ }^{32}$ There are two wider points here. The first is that populism can occur at various points on the political spectrum and is not the sole preserve of the political right. As Ignazi has observed, populism needs to be 'disentangled from its right-wing location'. ${ }^{33}$ Indeed, focusing on post-unification Germany, Decker and Hartleb have argued that 'the left-wing populism embodied in the PDS and new Left Party shows remarkable similarities to its right-wing counterparts, not only in its agitation-based style and methods, but also in programmatic and ideological terms' (my italics). ${ }^{34}$ Second, whereas left-wing and right-wing versions of populism have been defined principally in socio-economic terms, extreme-right or radical-right populism has been conceptualized in essentially socio-cultural terms - by reference to 'ethnic characterizations of the true people', for example. ${ }^{35}$ Thus, Mudde identifies the core ideological features of populist radical right parties as nativism, authoritarianism and populism and whilst it is clear that populism can be placed on a conventional left-right continuum, nativism is viewed as the ultimate determinant of this party family. It is defined as 'an ideology that holds that states should be inhabited exclusively by members of the native group ("the nation") and that non-native elements (persons and ideas) are fundamentally threatening to the homogenous nation-state'. ${ }^{36}$

${ }^{31}$ Mudde, Populist Radical Right Parties in Europe, pp. 29-30

${ }^{32}$ K. Abts and S. Rummens, 'Populism Versus Democracy', Political Studies, 55: 2 (2007), pp. 405-24.

${ }^{33}$ Ignazi, Extreme Right Parties in Western Europe, p. 30.

${ }^{34}$ F. Decker and F. Hartleb, 'Populism on Difficult Terrain: The Right- and LeftWing Challenger Parties in the Federal Republic of Germany', German Politics, 16: 4 (2007), pp. 434-54.

35 Abts and Rummens, 'Populism versus Democracy', p. 418.

${ }^{36}$ Mudde, Populist Radical Right Parties in Europe, p. 22. 
Rydgren also defines the new radical right in essentially sociocultural rather than socio-economic terms and like Mudde he, too, identifies three core ideological features. First, there is ethnonationalism, which involves fortifying the nation by making it ethnically homogeneous and by returning to basic values. Then there is populism, which has essentially involved accusing the political establishment of placing internationalism ahead of the nation and its own narrow self-interest before the interests of the people. Rydgren regards populism as a characteristic but not a distinctive feature of the new radical right. Rather, it is the combination of ethnonationalist xenophobia and anti-establishment populism that forms the quintessence of the radical right, which also embodies a general socio-cultural authoritarianism emphasizing the importance of law and order, family values, etc. He concludes that the new radical right is right-wing primarily in the socio-cultural sense of the term. ${ }^{37}$ It prioritizes socio-cultural issues and in particular those related to national identity.

The second part of this article follows a 'core ideological features' strategy in search of the PS' basic 'driving force'. The discussion is predicated on a 'qualitative content analysis' - that is, a careful reading and interpretation - of all the PS' programmatic output (the General Programme, election manifestos, statements of short-term policy goals, etc.) since 1995, including the manifesto for the European Parliament election in 2009. ${ }^{38}$ There are two obvious objections to this approach. Whilst definitions of populist radical right parties, such as those above, give precedence to socio-cultural over socioeconomic values, an examination of party literature does not permit entirely safe conclusions about dimension salience - that is, the relative

${ }^{37}$ J. Rydgren, 'The Sociology of the Radical Right', Annual Review of Sociology, 33 (2007), pp. 12.1-12.22.

38 The party literature studied is as follows: 'Oikeutta kansalle. Perussuomalainen Puolueen Yleisohjelma. Olen Perussuomalainen', Hyväksytty 1 puoluekokouksessa 26.11.1995 Kokkala; Perussuomalaisten eurovaaliohjelma 1999: Perussuomalainen kriitisenä Euroopassa; Perussuomalaisten lähiajan tavoiteohjelma - Oulu 17.6.2001; Perussuomalaisten eduskuntavaaliohjelma 2003. Uusi suunta suomelle - korjauksia epäkohtiin; Perussuomalaisten lähiajan tavoiteohjelma - Lappeenranta 2003; Perussuomalaisten lähiajan tavoiteohjelma - Kokkola 2005; Perussuomalaisten eduskuntavaaliohjelma 2007. Oikeudenmukaisuuden, hyvinvoinnin ja kansanvallan puolesta! - Ikaalainen 13.8.2006; Perussuomalaisten EU-vaaliohjelma 2009. Suomalaisena Euroopassa- kansanvallan puolesta.

(C) The Author 2010. Government and Opposition (c) 2010 Government and Opposition Ltd 
importance attached to particular policy content. There is always likely to be an element of expert (subjective) judgement involved and, in this respect, comparativists may well fall foul of the country specialist. Highly questionably, for example, Mudde classifies the Norwegian Progress Party as a neo-liberal populist party because he claims nativism does not form part of its core ideology whereas the Danish People's Party is (rightly) regarded as a clear-cut case of a populist radical right party. ${ }^{39}$ Furthermore, characterizing the spatial position of parties on the basis of programmatic themes inevitably simplifies the reality of party behaviour. In practice, parties are rarely unitary actors and internal factions and tendencies will differ in emphasis from the programmatic 'standard'.

\section{THE PS' POPULISM: CENTRE-BASED OR RADICAL RIGHTIST?}

Ultimately, of course, the spatial position of thought is bound to be somewhat arbitrary, which is presumably why O'Malley makes the point that "if it is not the economic right that is being referred to [in relation to radical right parties] it is unclear why the term "right" is employed'. ${ }^{40}$ Indeed, whilst the primacy of socio-cultural values may define radical right parties, we have already emphasized that populism is not the exclusive preserve of the political right and it may enjoy coordinate or indeed greater importance in the ideological fabric of a party than authoritarianism or ethno-nationalism. In relation to the socio-economic dimension of PS' populism, three fundamental party objectives warrant emphasis. The first has been a concern to integrate marginal groups into the mainstream of society and decision-making - that is, to ensure that the interests of the poor, vulnerable and disadvantaged, along with small entrepreneurs, gain the recognition they deserve, as well as providing them with a party through which they can exercise real influence. The General Programme in 1995 identified the party's target constituency as 'youngparent families, senior citizens, the unemployed, small and familysized enterprises and those engaged in agriculture and forestry'.

${ }^{39}$ Mudde, Populist Radical Right Parties in Europe, pp. 43-8.

${ }^{40}$ E. O'Malley, 'Why is there no Radical Right Party in Ireland?', West European Politics, 31: 5 (2008), pp. 960-77.

(C) The Author 2010. Government and Opposition (C) 2010 Government and Opposition Ltd 
A second party goal has been to provide basic economic security for citizens in all situations and, to achieve this, the PS advocates the traditional Nordic welfare state model based on the principle of universalism (extending services equally to all) and an active role for the state (central and local) as a welfare provider. Approximately one-third of the 2007 manifesto dealt with health and social care. There has been opposition to the way it is claimed that the Finnish welfare system has been scaled down as a result of the cynical implementation of EU strategies by a domestic political elite striving to encourage private schemes. Public-sector health care should not be directed primarily towards low-earners, senior citizens and the unemployed. Pointing to shortcomings in welfare provision for marginal groups, including war veterans (all now octogenarians) the PS' 2007 manifesto concluded that 'out of sight, out of mind is a monstrously Darwinian and completely misguided approach to decision-making'.

Finally, the PS has favoured a progressive system of taxation based on the individual's capacity to pay. The 2003 manifesto in particular demanded a drastic reduction in the tax on low-earners, proposing among other things a lowering of the vehicle and fuel tax and the VAT on basic foodstuffs and arguing that these measures would increase the purchasing power of poorer groups and thus reduce their need for social support. The taxation system should also create conducive conditions for small firms to hire extra labour. The 2003 manifesto concluded that the left had abandoned the poor and needy and that the traditional left of 'tailor Halme' and 'tenant farmer Koskela' - depicted by the writer Väinö Linna - no longer existed. 'In its stead, there is a cold, alien, Euro-socialist vanguard, which is viewed by traditional supporters as wealthy, leftist nobility that, from its exalted pedestal, knows what is best for the people'. In short, when viewed in traditional socioeconomic terms, the PS' populism has been 'left-leaning' or at least 'centre-left-inclined' in its concern to tackle fundamental social inequalities.

Interestingly, it has been noted that most populist radical rightist parties have been centre-based or even leftist on the dominant statemarket axis and relatively similar in that respect to the Christian Democratic family. Indeed, adapting the late Jörg Haider's depiction of the FPÖ's socio-economic policy as 'social, not socialist', ${ }^{41}$ the PS'

${ }^{41}$ Mudde, Populist Radical Right Parties in Europe, p. 130.

( $)$ The Author 2010. Government and Opposition @ 2010 Government and Opposition Ltd 
populism might be characterized as 'Christian social, not socialist' (Soini is a Catholic and there is extensive reference to Christian values in the PS' programmes). ${ }^{42}$ Incidentally, throughout its existence the PS has been seated in parliament to the left of the Centre Party.

Shortly after the 2009 European Parliament election, Erkki Havansi, one of the PS' candidates, held that his party combined traditional conservatism - the type he insisted still had support among a minority in the Centre and Conservative parties - and social radicalism, a view which prompted the response from a veteran Social Democrat that the PS' 'traditional conservatism' could readily be mistaken for social intolerance. ${ }^{43}$

The PS has unquestionably been traditionalist in its socio-cultural attitudes defending fundamental values and standards against those of the 'permissive society'. It has propounded a neo-Jeffersonian small-firm-small-farm model predicated on the belief that familysized enterprises generate the type of solid inter-personal relations which, when coupled with fundamental Christian values, provide a firm moral foundation for society. Correspondingly, the PS has taken a hard line on those insidious forces eroding the secure moral base of society and in particular those liberal attitudes perverting the traditional family concept. The 2003 manifesto noted, for example, that, over the course of the 'rainbow coalitions', the notion of the family has been broadened in a most unnatural way (same-sex relationships could be registered in 2002) and the door accordingly opened to an ever-deeper decay in the ethical base of society. Indeed, in connection with a law (enacted in May 2009) enabling one of the partners in a registered same-sex relationship legally to adopt the child of the other partner, the PS MP, Pentti Oinonen, expressed his dismay at the collapse of basic standards and stated (controversially, to put it mildly) that people would be seeking permission to marry their dogs next!

The PS has also taken a tough 'zero tolerance' line on drugs and alcohol abuse and demanded suitably punitive and effective

42 There are only 8,000 Catholics in Finland. Unto Hämäläinen, 'Henki voitti materian', Helsingin Sanomat, 14 June 2009.

${ }^{43}$ Erkki Havansi, 'Perussuomalaiset ovat arvokonservatiiveja', Helsingin Sanomat, 11 June 2009; Esko Helle, 'Arvokonservatiivit sulautunevat oikeistoon', Helsingin Sanomat,16 June 2009.

( ) The Author 2010. Government and Opposition @ 2010 Government and Opposition Ltd 
measures to deal with a deteriorating situation, including devoting more resources to policing. ${ }^{44}$ The 2007 manifesto pointed up the effect of drugs on crimes against the person and property, along with the increase in drug-related traffic accidents. It concluded that the PS is opposed to the liberal line on so-called 'soft drugs' adopted in some countries, not least because of the complex social problems that are stored up for the future. In short, the PS has been authoritarian rather than libertarian, espousing the authority and legitimacy of a Christian society grounded in traditional family values.

It will be recalled that ethno-nationalism or nativism - that is, strengthening the nation by making it ethnically homogeneous has been viewed as the ultimate determinant of membership of the populist radical right party family. In practice, in the globalized world of the new millennium, the threat to the homogeneity of the nation has come principally from the free movement of peoples and, as Ivarsflaten has observed, the grievances uniting all successful populist right parties have been those arising from Europe's ongoing immigration crisis. ${ }^{45}$ On the face of it, the party's stance on the immigration question has been moderate, at least at the rhetorical level. Soini has not resorted to the xenophobic extremism of the likes of the late Haider, insisting before the 2007 general election that demonizing other social groups and stirring racial hatred involved kicking the weak and that he did not want a victory at any price. The 2009 European Parliament election manifesto, moreover, held that whilst the 'old Finnish parties', plus the Greens, support a significant increase in the number of immigrants to meet the so-called labour shortage, the PS favours a responsible immigration policy. Equally, the PS has undoubtedly attracted racist elements, both candidates and voters. During the 2003 general election, Halme used the kind of racist and homophobic language commonly associated with the radical right ${ }^{46}$ whilst at the 2008 local election Jussi Halla-aho, standing as an Independent on the PS list

${ }^{44}$ Plainly, Tony Halme's descent into drugs, depression, extended sick leave from parliament and ultimate suicide early in 2010 was not the role model with which the PS wanted to be associated!

${ }^{45}$ E. Ivarflaten, 'What Unites Right-Wing Populists in Western Europe?: Re-examining Grievance Mobilization Models in Seven Successful Cases', Comparative Political Studies, 41: 3 (2008), p. 18.

${ }^{46}$ E. Kestilä, 'Is there Demand for Radical Right Populism in the Finnish Electorate?', Scandinavian Political Studies, 29: 3 (2006), p. 175.

() The Author 2010. Government and Opposition @ 2010 Government and Opposition Ltd 
for Helsinki, attracted considerable notoriety - as well as a sizeable vote - following his idiosyncratic characterization of Muslim attitudes. Moreover, despite his moderate leadership style, 40 per cent of respondents in a Suomen Gallup poll before the 2008 local election viewed Soini as either 'openly racist' (12 per cent) or 'a racist who tries to hide it in public' (28 per cent).

The PS' literature indicates an apparent hardening of the party line on foreigners and illustrates the way policy positions evolve and change over time. In its inaugural 1995 General Programme, the PS' attitude to foreigners could perhaps best be described as one of conditional tolerance. 'We accept foreigners living and working in Finland, but will not allow any of them to come and damage our "people's home" (kansankoti). They must respect our society and judicial procedures so that we in turn accept their cultures and contrasting backgrounds and give them the right to live among us on an equal footing.' The 2003 manifesto insisted that Finland should not develop a separate approach to immigrants and asylumseekers, but rather they should be dealt with as an integral part of a wider 'population policy'. Finland's peripheral location, it was argued, had given it a big advantage in respect of demographic and race-related problems. Finland did not need to keep foreigners out. Yet by 2007 the PS' general election manifesto for the first time contained a separate section on asylum policy and immigration, though it was the ninth section and accounted for under 4 per cent of the overall text. On the basis of this manifesto, two intertwined threads in the party's attitude towards immigrants are worth separating out.

First, the PS is mono-culturalist rather than multi-culturalist in orientation, opposed to wholesale immigration whilst pursuing a line of what might be termed comprehensive acculturation - a basic 'when in Rome, do as the Romans do' approach. The 2007 manifesto asserts that it is not sensible to create a system where persons come to Finland simply to spend time and find happiness whilst officials seek artificially to preserve the immigrant's own culture. Preserving their culture is the immigrants' own business and public resources should not be expended on it, as it does not directly assist in the integration of immigrants into Finnish society. 'We can never accept those decisions which involve urging the native population to sacrifice their own traditions to accommodate foreign cultures. Multiculturalism should not be promoted at the expense of the 
Table 2

The Population of Foreign Citizens in West European States in 2008 (\% of total population)

\begin{tabular}{lllc}
\hline State & $\begin{array}{l}\text { \% foreign } \\
\text { citizens }\end{array}$ & State & $\begin{array}{c}\text { \% foreign } \\
\text { citizens }\end{array}$ \\
\hline Finland & 2.5 & Germany & 8.8 \\
Denmark & 5.5 & Belgium & 9.1 \\
Norway & 5.6 & Austria & 10.0 \\
Sweden & 5.7 & Spain & 11.6 \\
France & 5.8 & Ireland & 12.6 \\
Italy & 5.8 & Switzerland & 21.1 \\
UK & 6.6 & Luxembourg & 42.6 \\
Greece & 8.1 & & \\
\hline
\end{tabular}

Source: Eurostat: Statistics in Focus $94 / 2009 .{ }^{47}$

native culture.' The manifesto maintained that since the present body of immigrants does not really try to integrate into society but instead, as in Sweden, constitutes ethnic sub-cultures, large-scale immigration will ultimately threaten the indigenous Finnish culture. It might be noted here that in 2008 Finland had the lowest proportion of foreign citizens as a percentage of the total population of any West European state and, whereas in Germany there were 7.3 million foreign citizens, in Spain 5.3 million and the United Kingdom 4 million, there were only 133,000 in Finland (see Table 2).

Second, the PS is welfare chauvinist in the sense that the welfare of the native population must come first and should not be deleteriously affected by immigration. Of particular concern has been the position of young persons and young-parent families. The PS manifesto insisted that Finland did not need significant numbers of immigrants to meet a possible labour and skills shortage but rather vocational education should be increased and its quality improved. It held that too many young persons were being channelled into an academic route at the end of which there was no guarantee of a job. Many also incurred levels of debt (in the form of student loans) that delayed the start of a family because no child benefit was built into the student support system. If nothing was done, Finland would witness the emergence of a white-collar proletariat whose work and family life would

${ }^{47}$ For a good discussion of the facts and figures on immigration in Finland, see Mervi Virtanen, 'Maahanmuuton faktat tiedettävä’, Helsingin Sanomat, 17 August 2009.

(C) The Author 2010. Government and Opposition (C) 2010 Government and Opposition Ltd 
rest on a shaky foundation. Finnish society, too, would rest on a precarious base in so far as racism would breed in a situation in which, short-sightedly, immigrants and foreign labour were available whilst the native population was experiencing difficulties in obtaining work.

A case has been made for viewing the PS as a centre-left populist party. Paloheimo and Raunio have claimed that 'in a wider European perspective both the SMP and its successor the PS are centred-based populist parties'. ${ }^{48}$ Whilst they do not develop or elaborate on this assertion, a prima facie defence of the proposition might involve the following three points. First, as a successor party, the PS has 'inherited' many of the fundamental features of Vennamo-ism, and Vennamo-ism was certainly not right-wing populism in the mould of the contemporary anti-tax, anti-bureaucracy Progress Party in Denmark or the latter's sister (Anders Lange) party in Norway. Rather, the SMP broke through at a time of accelerated social structural change and embodied what in socio-economic terms was a left-leaning, anti-establishment populism that championed the cause of the 'forgotten Finns' ${ }^{49}$ Helander and Toivonen portrayed the early SMP as a non-socialist left party ${ }^{50}$ although it needs emphasizing that Vennamo-ism also embraced a strong, right-inclined socio-cultural authoritarianism. In any event, the PS' populism has never flirted with neo-liberalism and has consistently advocated an active role for the state as a welfare provider based on the principle of universalism.

${ }^{48}$ H. Paloheimo and T. Raunio, 'Suomen puolueiden nykytila ja tulevaisuuden haasteet', in H. Paloheimo and T. Raunio (eds), Suomen puolueet ja puoluejärjestelmä, Porvoo, WSOY, 2008, p. 213.

${ }^{49}$ In his Kornhauser-inspired analysis of the SMP's breakthrough, written shortly after the 1970 earthquake election, Sänkiaho traced the sources of the alienation he viewed as underpinning support for Vennamo-ism to the shift from a traditional to mass society - that is, the anomic impact of accelerated industrialization and urbanization. R. Sänkiaho, 'A Model of the Rise of Populism and Support for the Finnish Rural Party', Scandinavian Political Studies, 6 (1971), pp. 27-47. For a rather polemical analysis of the SMP's success in 1970, which emphasizes the way all the parties had failed the smallholders, whose standard of living had fallen, see E. Poutiainen, Melkoisen kovaa leikkiä, Helsinki, Tammi, 1972, pp. 174-7.

${ }^{50}$ V. Helander and T. Toivonen, 'Vennamolaisuus populismin ideoiden heijastana', in V. Helander (ed.), Vennamolaisuus populistisena joukkoliikkeenä, Hämeenlinna, Karisto, 1971, p. 65.

(C) The Author 2010. Government and Opposition (C) 2010 Government and Opposition Ltd 
Second, although the PS' electorate conforms rather closely to that of the archetypal radical rightist voter ${ }^{51}$ and its voters are the most hostile of all the parties to increased immigration,,$^{52}$ the PS supporters have not seen it as a right-wing party. They display relatively low levels of party identification ${ }^{53}$ and have substantially lower than average levels of political trust in politicians. ${ }^{54}$ On the basis of the 2007 general election survey, moreover (albeit with a low $\mathrm{n}=$ $44)$, the PS' voters were preponderantly working class, male and derived overwhelmingly from the age cohorts under 44 years. The proportion of workers among PS supporters (53.5 per cent) was the highest of any of the parliamentary parties. ${ }^{55}$ But in support of Paloheimo and Raunio, the 2007 election survey indicated that PS supporters were situated to the left of the Centre Party and perceived themselves as the most left-wing of the non-socialist parties. ${ }^{56}$

Finally, and more tenuously, the PS emerged from a populist movement and not from an extremist right-wing tradition as in the case of the Front National ${ }^{57}$ or Sweden Democrats, ${ }^{58}$ and its rhetoric and leadership style have been moderate compared with the xenophobic extremism of the Danish People's Party, the FPÖ or Geert Wilders' Party for Freedom (PVU) in Holland. There has been no insistence on the threat posed by 'Islamization', proposals of the type of Haider's sonderlager - a special camp for the elderly, sick and

${ }^{51}$ M. Lubbers, M. Gijssberts and P. Scheepers, 'Extreme Right-Wing Voting in Western Europe', European Journal of Political Research, 41 (2002), pp. 345-78. W. Brug, M. van der Fennema and J. Tillie, 'Anti-Immigrant Parties in Europe: Ideological or Protest Vote?', European Journal of Political Research, 37 (2000), pp. 77-102.

52 'Maaseudulla asuvat ja työväestö kielteisimpiä maahanmuuttoa kohtaan', Helsingin Sanomat, 17 March 2009.

${ }^{53}$ H. Paloheimo and J. Sundberg, 'Puoluevalinnan perusteet', in Paloheimo, Vaalit ja demokratia Suomessa, p. 200.

${ }^{54}$ H. Paloheimo, 'Ideologiat ja ristiriitaulottuvuudet', in Paloheimo and Raunio, Suomen puolueet ja puoluejärjeastelmä, p. 53.

${ }^{55} \mathrm{I}$ am indebted to Heikki Paloheimo for these data.

${ }^{56}$ H. Paloheimo, 'Ideologiat ja ristiriitaulottavuudet', in Paloheimo and Raunio, Suomen puolueet ja puoluejärjeastelmä, p. 39.

${ }^{57}$ J. Rydgren, 'Explaining the Emergence of Radical Right-Wing Populist Parties: The Case of Denmark', West European Politics, 27: 3 (2004), p. 497.

${ }^{58}$ A. Widfeldt, 'Party Change as a Necessity: The Case of the Sweden Democrats', Representation, $44: 3$ (2008), pp. 265-76. J. Rydgren, From Tax Populism to Ethnic Nationalism: Radical Right-Wing Populism in Sweden, Oxford and New York, Berghahn Books, 2006 . 
criminal asylum-seekers on an isolated 1,200-metre-high alpine pasture $^{59}$ - or wholesale repatriation.

Yet an analysis based on its core ideological features does not support the PS' characterization as a centre or centre-left populist party. Rather, the mix of traditional conservatism (socio-cultural authoritarianism) and ethno-nationalism (nativism) defines the PS as a spin-off party ${ }^{60}$ - a populist radical right party endorsing many of the themes of its harsher continental counterparts. There was inter alia rejection of the Lisbon Treaty that came into force in December 2009, continuing opposition to Turkish membership of the EU and indeed any further renunciation of national sovereignty. This has been coupled with support for the immediate deportation of criminal asylum-seekers, protection for domestic agriculture and industry and tougher penalties for drug-abusers, etc. Crucially, the central concept in the PS' ideology - and one that permeates the entire party literature - is the notion of (true) Finnishness. The term appears widely in PS texts. The 2009 European Parliament manifesto, for example, contains sections entitled 'Finnishness is strength' and 'Finnishness is a competitive advantage' and it insists that Finnishness is cultural capital which should be capitalized upon and not dissipated. It held somewhat obscurely that 'society and nation go hand in hand towards the future and if we as a nation are not able to influence society and if society has no nation to influence we will lose our competitive edge over less successful countries in which society and nation are less well integrated than in Finland.' Finnishness is the pivotal, pre-eminent concept and the PS' basic geist. It is that which defines the PS as belonging to the family of radical right parties ${ }^{61}$

\section{CONCLUSIONS}

Contrary to the conventional wisdom among Finnish political scientists who have viewed the PS as a 'centre-based populist party' or the

59 'Haider is our Lady Di', Guardian, 18 October 2008.

${ }^{60}$ J. Rydgren, 'Is Extreme Right-Wing Populism Contagious? Explaining the Emergence of a New Party Family', European Journal of Political Research, 44: 3 (2005), pp. $428-9$.

61 'Finnishness' was also a core component in the SMP's 1992 Programme. See R. Mickelsson, Suomen Puolueet, Historia, muutos ja nykypäivä, Jyväaskylä, Gummerus, 2007, pp. 309-10.

๑ The Author 2010. Government and Opposition @ 2010 Government and Opposition Ltd 
'most left-wing of the non-socialist parties', this article has argued on the basis of the core nature of nativism or ethno-nationalism in the party's ideological armoury - that the True Finn Party is best classified as a populist radical right party in the West European tradition. The party's anti-immigrant rhetoric has undoubtedly been less extreme than say the Danish People's Party but, not insignificantly, Soini, its leader, now rubs shoulders with two Danish People's Party MEPs as part of the newly formed, 30-strong Europe of Freedom and Democracy grouping in the European Parliament headed by the United Kingdom Independence Party (UKIP) leader Nigel Farage.

The article has also made the case for a hardening of the party's line on foreigners - for the first time in the 2007 election manifesto there was a separate section on asylum policy and immigration - although it might reasonably be speculated that (thus far) the populist anticonsensus character of the PS has been more appealing to most of its voters than its nativist credentials. Populist parties have generally been leader-dependent, context-dependent and drawn on the most volatile sections of the electorate. On the point of leadership dependency, Soini's belated decision to run for the European Parliament was largely designed to capitalize on his personal popularity, maintain the party's media profile and above all prepare the way for a strong PS performance at the April 2011 general election. However, populist parties have been notoriously prone to factional strains - the 'parent' SMP is a case in point - and, with Soini spending significant amounts of time in Brussels/Strasbourg, maintaining the unity, drive and direction of the party as an 'extern' chair will be highly challenging.

On the point of context dependency, the PS undoubtedly profited in the local and European Parliament elections from a widespread anti-establishment, anti-party mood spawned of revelations about MPs' election funding. Undeclared contributions from corporatesector sources created a strong sense of 'sleaze' (much as in the UK over MPs' expense claims) and a widespread sentiment of 'a plague on all your houses' among the public at large. The PS could continue to profit from this - particularly during present economic hard times - not least as, almost daily, fresh murky revelations appear in the press, although the ability of the PS leadership to continue to rein in the racist elements attracted to the party will be crucial. The 2009 European Parliament election campaign triggered a debate about immigration for really the first time in Finland, during which a number of controversial views from high-profile politicians were

(C) The Author 2010. Government and Opposition (C) 2010 Government and Opposition Ltd 
expressed $^{62}$ and a concerted attempt made by the other parties to tar the PS with the racist brush. It is highly doubtful if the PS could continue to grow as a blatantly (Danish-style) racist party and the recruitment of both sufficient, and as importantly suitable, candidates for the 2011 general election will be vital to its continuing success. ${ }^{63}$

Finally, there is the highly volatile nature of the PS' support base. Indeed, it should be remembered that the PS' 9.8 per cent in the European Parliament poll was achieved in a 'second-order election' and would not necessarily be replicated in a general election, although before midsummer 2010 PS registered 9.1 per cent in the opinion polls. The wider point here though concerns the PS' middle-term strategic direction. On the one hand, as a populist party it must retain its protest appeal to attract votes. On the other, Soini has indicated that he has not ruled out participation in government if and when the PS doubles its present contingent of five MPs. Mény and Surel have noted that populist parties 'are by nature neither durable nor sustainable parties of government. Their fate is to be integrated into the mainstream or to remain permanently in opposition. ${ }^{64}$ Under both Vennamos - Veikko and particularly his son Pekka - the SMP was an office-seeking party and indeed formed part of the governing coalitions between 1983 and 1990. However, the loss of its antiestablishment credentials significantly undercut the SMP's vote and radical image. The participation of the FPÖ in the Austrian coalition between 2000 and 2005 worked the same way. The rise of the PS has witnessed the breakthrough of another West European populist radical right party but the wider question will be whether, in Finland and elsewhere, a populist radical right party can continue to appear radical except as an anti-political-establishment party.

${ }^{62}$ For example, the Helsinki City Council leader, Jussi Pajunen, claimed that Helsinki was failing in its aim of converting the flow of immigrants into a source of economic strength. Rather, he claimed that the reverse was the case and that action was needed to restrict immigration. He noted that the proportion of capital city inhabitants with an immigrant background had risen from 2 per cent in the early 1990s to nearly 10 per cent and that at the present rate every fourth Helsinki dweller would have an immigrant background by 2025. 'Jussi Pajunen jarruttaisi maahanmuuttoa', Helsingin Sanomat, 1 December 2008.

63 'Eniten luopujia on Sdp:n riveissä', Helsingin Sanomat, 9 February 2010.

${ }^{64}$ Mény and Surel, 'The Constituent Ambiguity of Populism', in Democracies and the Populist Challenge, p. 18.

(C) The Author 2010. Government and Opposition (c) 2010 Government and Opposition Ltd 